\title{
Hvorfor benchmarker kommunerne?
}

\author{
Marie-Louise Frølich Brødsgaard \\ stud.scient.pol., Institut for Statskundskab, Københavns Universitet \\ Mathias Gjørling \\ stud.scient.pol., Institut for Statskundskab, Københavns Universitet
}

Benchmarking i den kommunale sektor bliver stadig mere udbredt. Sammenligninger på tværs af kommunerne gør det muligt at styre efter resultater; men det er ikke sikkert, at denne mulighed for styring er nok til at forklare, hvorfor kommunerne benchmarker.

\section{Indledning}

I hvilken kommune er udgifterne pr. skoleelev højest? Hvor bliver der brugt flest penge på snerydning? Hvem kan tilbyde flest plejehjemsboliger pr. indbygger over 65 år? Svarene på disse spørgsmål findes i kommunale nøgletal. I dag udbydes nøgletal fra mange forskellige sider: KL, Økonomi- og Indenrigsministeriet, Danmarks Statistik og KORA er blot nogle af dem, der ud over kommunerne selv producerer nøgletal om den kommunale sektor. Med så mange udbydere af nøgletal fristes man til at spørge: Hvad bidrager nøgletallene med?

Siden 1985 har Aarhus, Odense, Aalborg, Esbjerg og Randers hvert andet år produceret en nøgletalsrapport med nøgletal for service- og udgiftsniveauer på forskellige forvaltningsområder som fx ældre- og handicapområdet, folkeskolen, kollektiv transport og tandplejen. I 2003 tilsluttede København sig nøgletalssamarbejdet, der i dag benævnes 6-bynøgletalssamarbejdet (Københavns Kommune 2013). 6-bynøgletalssamarbejdet er et eksempel på resultatstyring i den offentlige sektor, der stammer helt tilbage fra den gang, styringsfænomenet første gang kom på dagsordenen.

Denne artikel undersøger bevæggrunden for og effekterne af resultatstyring i den del af den offentlige sektor, der udgøres af kommunerne. Konkret undersøger vi 6-bynøgletalssamarbejdet mellem Danmarks seks største bykommuner. Vi arbejder ud fra følgende forsknings- spørgsmål: Hvorfor deltager Danmarks seks storste bykommuner $i$ et frivilligt nogletalssamarbejde?

Nøgletal i en dansk kommunal kontekst er mål, som enheder sammenlignes på (Konkurrencestyrelsen 1998, 7). Der hersker en forestilling om, at den offentlige sektor mangler de markedsmekanismer, der i den private sektor fremmer effektivitet og kvalitet (Bukh 2007, 2). I mangel af disse markedsmekanismer kan der med benchmarking opstilles en fælles referenceramme for vurdering af indsatser på tværs af funktionelt ens enheder (Siverbo \& Johansson 2006, 274). Anvendelsen af nøgletal i den kommunale sektor kan i den sammenhæng beskrives som resultatbenchmarking (Bukh 2007a, 22), hvor der fokuseres på aggregerede og kvantificerbare resultater. I denne artikel forstår vi benchmarking som en bevidst aktivitet, der udføres i bestræbelserne på at kvantificere resultater, så de systematiske sammenligninger af performance kan udgøre en referenceramme for vurdering og styring af ensartede enheders opgavevaretagelse.

Artiklen anvender den brede definition af resultatstyring, der blev præsenteret i temanummerets indledning, hvor resultatstyring er en styring, der inkorporer og anvender resultatinformation i beslutningstagen. Resultatinformation er produktet af en resultatmålingsproces, der består af en række aktiviteter: at fokusere målingsindsatsen, udvælge indikatorer samt indsamle, analysere og rapportere data. Ud fra denne definition kan benchmarking ses som en type resultatstyring, der opgør relative præstationer, og som har fået en stigende betydning i den kommunale sektor.

Med få undtagelser (Olsen forthcoming; Siverbo \& Johansson 2006; Triantafillou 2007; Van Helden \& Tillema 2005) er der ikke foretaget undersøgelser af effekterne af anvendelsen af benchmarking. Den udbredte anvendelse af benchmarking og den manglende systema- 
tiske viden om effekterne heraf er med til at øge relevansen af vores undersøgelse.

Nedenfor opstiller vi i afsnit 2 det teoretiske apparat. I afsnit 3 præsenterer vi kort forskningsdesign samt metodiske valg. I afsnit 4 analyserer vi, om kommunernes deltagelse i nøgletalssamarbejdet kan forstås ud fra de observerede effekter. I afsnit 5 diskuterer vi på baggrund af analysen forklaringer på, hvorfor kommunerne fortsat deltager i nøgletalssamarbejdet, og i afsnit 6 samler vi op på artiklens fund.

\section{Analyseramme}

Centralt for undersøgelsens teoretiske ramme er forståelsen af kommuner som organisationer og begrebet effekt.

\section{Kommunerne som organisation og effekter som organisatorisk handling}

Kommunerne i Danmark er politisk ledet offentlige organisationer, som varetager hovedparten af de opgaver, der udgør vores velfærdsstat. Det forventes, at kommunerne leverer et tilfredsstillende serviceniveau, opretholder en bæredygtig økonomi samt lever op til befolkningens krav om anvendelse af de rette idéer, ideologier og metoder. Succes for kommunerne er derfor både bæredygtig økonomi og legitim adfærd.

$\mathrm{Vi}$ anvender, jf. indledningen til temanummeret, Brunsson (2002) og udvidelsen ved Pollitt (2001) som teoretisk grundlag for analysen af, om effekterne af anvendelsen af nøgletallene kan forklare, hvorfor kommunerne deltager i nøgletalssamarbejdet. Vores udgangspunkt er en socialkonstruktivistisk tilgang med organisationer som åbne systemer og et fokus på organisationers behov for legitimitet. Meyer og Rowan (1977) påpeger, at $\mathrm{i}$ jagten på legitimitet skal organisationer tilfredsstille både et teknisk og et institutionelt miljø (Brunsson 2002, 6). Det tekniske miljø vurderer kommunerne ud fra krav til produkter og resultater, hvorimod det institutionelle miljø vurderer organisationer ud fra krav til struktur, processer og ideologier.

Kravene fra det institutionelle og tekniske miljø kan tilfredsstilles på forskellig vis, dvs. gennem forskellige organisatoriske handlinger. Vi fremhævede i indledningen til temanummeret dette som en skelnen mellem det retoriske og det praktiske plan. Brunsson og Pollitt opstiller fire typer organisatorisk handling: tale, beslutninger, handlinger og resultater. Strukturer, processer og ideologier hos organisationer kommer til udtryk gennem tale og beslutninger. Disse organisatoriske handlinger relaterer sig derfor primært til det institutionelle miljø, og hvad der i indledningen blev kaldt det retoriske plan. Organisationers produkter og resultater kan ses i de organisatoriske handlinger som Brunsson og Pollitt kalder handlinger og resultater. Det er dermed gennem handlinger og resultater, at det praktiske plan adresseres, og at kravene fra det tekniske miljø tilfredsstilles.

Tale forstås af Brunsson som både det skrevne og talte ord. Tale produceres både til organisationen internt og til omgivelserne (Brunsson 2002, 26). Tale vil typisk producere og promovere ideologier. Beslutninger er en særlig type tale, der har en mere formel karakter (Brunsson 2002, 26). En politisk organisation skaber beslutninger, som den efterfølgende promoverer. Det kunne fx være en beslutning om at nedbringe enhedsomkostningerne på ældreområdet. Tale og beslutninger kan ses som et udtryk for en hensigt om forandring.

Handling forstås af Brunsson primært som fysiske produkter (Brunsson 2002, 26) og dermed som egentlig produktion. I denne artikel forstås det dog også som serviceydelser som $f_{x}$ sagsbehandling. En handling kunne fx være større brug af velfærdsteknologi på ældreområdet med henblik på at nedbringe enhedsomkostningerne ved hjemmeplejen. Pollitt tilføjer den fjerde type organisatorisk handling: resultater. Det gør han ud fra et argument om, at to ens handlinger i forskellige kontekster kan føre til forskellige outcomes, hvilket Brunssons tre typer ikke kan indfange (Pollitt 2001, 940). Pollitts resultater omhandler i relation til kommunerne fx enhedsomkostninger eller kvalitetsniveau. Både handlinger og resultater kan ses som et udtryk for faktiske forandringer.

De fire typer organisatorisk handling gør det muligt at få en bred forståelse af effekterne af kommunernes anvendelse af benchmarking. Effekterne af anvendelsen af benchmarking kan både komme til udtryk som en hensigt om forandring gennem tale og beslutninger, men også som faktiske forandringer $\mathrm{i}$ form af handlinger og resultater. De tidligere artikler i dette temanummer har fokuseret på de diskursive eller retoriske elementer af resultatstyring i den offentlige sektor, men vi inkluderer det praktiske plan og fokuserer både på hensigten om forandringer og på de faktiske forandringer, der finder sted på baggrund af anvendelsen af benchmarking i den kommunale sektor. Analyserammen er afspejlet i figur 2.1 nedenfor.

Figur 2.1: Effekter som organisatorisk handling

\begin{tabular}{|c|c|c|c|}
\hline \multicolumn{2}{|c|}{$\begin{array}{c}\text { Den politiske } \\
\text { organisation } \\
\text { (Hensigt om forandring) }\end{array}$} & \multicolumn{2}{|c|}{$\begin{array}{l}\text { Den handlende } \\
\text { organisation } \\
\text { (Faktisk forandring) }\end{array}$} \\
\hline Tale & Beslutning & Handling & Resultater \\
\hline \multicolumn{3}{|c|}{ Brunsson } & Pollitt \\
\hline
\end{tabular}

Kilde: Brødsgaard \& Gjørling 2015, 50. 


\section{Metodiske refleksioner}

\section{Forskningsdesign}

Casen for vores undersøgelse er 6-bynøgletalssamarbejdet. Udgangspunktet for vores caseudvælgelse har været at maksimere casens informationsindhold i forhold til teorien (Bøgh Andersen et al. 2010, 89), dvs. at vælge et fertilt eksempel (Polkinghorne 2005, 140). Særligt bygger caseudvælgelsen på den eksisterende litteraturs pointe om, at et frivilligt indgået benchmarkingsamarbejde er en most-likely case (Askim et al. 2007; Siverbo \& Johansson 2006). Pointen bygger på antagelsen om, at kommunerne $\mathrm{i}$ et frivilligt indgået samarbejde $\mathrm{i}$ højere grad end i tilfælde med ikke-frivilligt engagement er interesserede $i$, at analyserne får (positive) effekter. Caseudvælgelsen kan karakteriseres som purposive selection (Polkinghorne 2005, 140).

Vi ser 6-bynøgletalssamarbejdet som én case på ét tidspunkt, hvor alle seks kommuner inddrages for at øge antallet af observationer. Undersøgelsen er et singlecasestudie.

Det analytiske niveau for vores undersøgelse er kommunen som samlet organisation, hvor dele af organisationen henfører til forskellige miljøer (Brunsson 2002, 6). Vi skelner uanset kommunal styreform mellem tre organisatoriske niveauer: politikere, den centrale forvaltning og den decentrale forvaltning, jf. tabel 3.1. Denne opdeling er foretaget for at standardisere de niveauer, data er tilknyttet. Standardiseringen er foretaget ud fra en vurdering af de hierarkiske relationer mellem forvaltningsdelene.

De kommunale institutioner er ikke inddraget, da vores informanter samstemmende pegede på, at medarbejderne $\mathrm{i}$ institutionerne ikke er med til at udarbejde nøgletallene og ikke anvender dem.

Dataindsamlingen er fokuseret til to decentrale fagforvaltninger - biblioteksområdet og ældreområdet - for at afgrænse dataindsamlingen på det decentrale forvaltningsniveau og mindske aktøreffekten, så én eller få observationer ikke får en uforholdsmæssig stor indflydelse. Vi har udvalgt områderne efter en stratificeret tilfældig udvælgelse af to af nøgletalsrapportens emner opdelt efter politisk saliens. Emnernes saliensniveau har vi vurderet ud fra data fra valgundersøgelsen (Stubager et al. 2013) sammenholdt med en undersøgelse foretaget af YouGov i forbindelse med det seneste kommunalvalg (Baes-Jørgensen 2013). Ved at vælge de to områder kan vi desuden undersøge, om vores fund er influeret af saliens. Vores undersøgelse indikerer, at det ikke er tilfældet.

\section{Metode}

Data er indsamlet ved kvalitative interviews. Vores valg af metode gør det muligt at undersøge sammenhængen mellem intentionen og effekterne af anvendelsen af benchmarking på forskellige organisatoriske niveauer med udgangspunkt i, hvordan processen opleves af de mennesker, der beskæftiger sig med det (Polkinghorne 2005, 138).

Informanterne er udvalgt ved en snowballingstrategi (Polkinghorne 2005, 141), der tog udgangspunkt i nøgletalssamarbejdets kontaktpersoner. Informanterne fremgår af bilag 1 .

\section{Intention og effekt af anvendelse af benchmarking}

For at besvare, hvorfor Danmarks seks største bykommuner deltager i et frivilligt nøgletalssamarbejde, analyserer vi sammenhængen mellem hhv. intentionen med nøgletalssamarbejdet og effekterne af anvendelsen af 6-bynøgletallene.

\section{Intentionen med nøgletalssamarbejdet}

På baggrund af vores interviews ${ }^{1}$ stod det klart, at det er vigtigt for kommunerne at kunne sammenligne sig for at kunne forbedre sig:

„Vi skal jo gøre det så effektivt som muligt og så godt som muligt, så vi kan hele tiden lære af hinanden. Og på den måde er 6-bynøgletallene jo en god indikator på, hvor kan vi lære af hinanden. Så det er nødvendigt. Forbedringer ... for at gøre det bedre, få borgeren i centrum og alt sådan noget." (Informant P, 4)

„Man kan sige, det er jo et udtryk for, at man gerne vil udstikke en retning: 'Okay, vi har de her tal, dem vil vi gerne performe bedre på næste år' - eller vi har en forventning om, at vi vil kunne blive bedre." (Informant $\mathrm{O}, 2$ )

Intentionen med nøgletalssamarbejdet er, jf. citaterne ovenfor, at kunne forbedre kommunens opgavevaretagelse. Et skridt på vejen til denne forbedring er læring (Informant M, 7; Informant I, 3; Informant S, 7), hvilket peger på et behov for at anvende nøgletallene til at skabe et overblik over kommunens placering og undre sig over den (Informant M, 2; Informant $\mathrm{O}, 3-4$ ). At opnå forbedringer kræver dog en reel ændring i organisatorisk adfærd (Behn 2003). Anvendelsen af nøgletal får således først den ønskede effekt, når anvendelsen fører til forandringer. 
Tabel 3.1: Organisatoriske niveauer i analysen i forhold til i 6-byerne

\begin{tabular}{ll}
\hline Forvaltningsniveauer i analysen & Forvaltningsniveauer i 6-byerne \\
\hline Politikere & Politikere \\
Central forvaltning & $\emptyset k$ konomiforvaltningen, borgmesterens afdeling \\
Decentral forvaltning & Magistratsafdelinger, sektorforvaltninger, Fagforvaltninger \\
\hline
\end{tabular}

Kilde: Brødsgaard \& Gjørling 2015, 62.

Her peger kommunerne på, at den ønskede effekt er faktiske forandringer i service- og udgiftsniveauer. Ifølge kommunernes eget rationale deltager de i et frivilligt nøgletalssamarbejde for at opnå effekter, der falder i tråd med de typer organisatoriske handlinger, som Brunsson og Pollitt kalder handlinger og resultater.

\section{Effekter af den faktiske anvendelse af 6-bynøgletallene} Én ting er intentionen, noget andet er de faktiske effekter af anvendelsen af nøgletalsrapporterne. I dette afsnit undersøger vi, hvilke forandringer i form af organisatoriske handlinger, der kan knyttes til kommunernes anvendelse af 6-bynøgletallene.

\section{Effekter på det politiske niveau}

Politikernes anvendelse af nøgletalsrapporten har effekter i form af tale og beslutninger, mens der ikke kan identificeres effekter i form af handlinger og resultater.

Når nøgletallene viser, at kommunen ikke lever op til politikernes forventninger til hhv. udgifts- og serviceniveauer, kan det give plads til forandring. I de situationer bliver nøgletallene baggrunden for politikernes hensigt om forandring; en hensigt, der kommer til udtryk gennem tale. Vores empiri peger på, at de utilfredsstillende tal oftest leder til defensiv tale, hvor politikerne i forventning om andres ønsker om bedre resultater argumenterer for, hvorfor situationen skal forblive uforandret (Informant A, 13; Informant H, 1-2; Informant L, 9-10; Informant $\mathrm{M}, 9-10)$. Et konkret eksempel er gengivet $\mathrm{i}$ citatet nedenfor.

„Det kunne også have været op til et kommunevalg, hvor nogle andre siger, at [kommunen] er en dyr kommune at administrere. Den er administrativ tung - eller sådan et eller andet. Så kommer [nøgletalsrapporten] også i spil." (Informant K, 30)

Citatet giver udtryk for en situation, hvor kommunen bliver kritiseret for at have for høje administrationsudgifter, hvortil nøgletalsrapporten anvendes som dokumentation for, at kommunen i sammenligning med andre kommu- ner ikke har så høje udgifter. Her får anvendelsen således effekt i form af, hvad der kan kategoriseres som defensiv tale, eftersom nøgletalsrapporten bruges som argumentere mod påstanden om, at kommunen er ineffektiv på administrationsområdet.

Hensigten om forandring kommer også til udtryk på det politiske niveau i form af beslutninger:

„Det er klart, [politikerne] bruger det nogle gange som argument og nogle gange til at sige, at man skal spare eller bruge flere penge, eller hvad de nu ellers har af synspunkter. Så et meget konkret argument for at gøre noget på en anden måde. Helt aktuelt er der en diskussion om byggesagsgebyrer, hvor [man ser på]: 'Hvordan ser det ud i andre kommuner, opkræver de gebyrer? Hvor store er de?' Det er et meget konkret eksempel.“" (Informant F, 2)

Det fremhæves dog også, at politikerne ikke systematisk anvender nøgletallene til at træffe beslutninger, men at nøgletallene i stedet inddrages som argumentation, når det passer ind i politikernes dagsorden:

„Jeg synes, det er meget ad hoc præget. Og det kan være meget politisk præget. Så pludselig dukker der noget op, og så bliver [nøgletallene] brugt.“ (Informant G, 6)

Det fremgår af citatet, at nøgletallene anvendes til at træffe beslutninger, men at denne proces er præget af, at argumenterne findes til lejligheden. Dertil er der få beslutninger, der foretages ud fra nøgletalsrapporten, relativt til det samlede antal politiske beslutninger (Informant $\mathrm{H}$, 2). Informanterne peger på, at politikerne anvender nøgletalsrapporten til at træffe beslutninger, men de har kun få konkrete eksempler til at illustrere det (Informant N, 2; Informant $\mathrm{H}, 2$ ). Vi vurderer, at det kan skyldes to ting: enten at der er tale om intentioner for anvendelsen af nøgletalsrapporten, eller at nøgletalsrapporten skaber en baggrundsviden om kommunens forskellige udgifts- 
og serviceniveauer, som politikerne efterfølgende, når de træffer beslutninger, trækker på uden eksplicit at referere til nøgletallene.

Det var generelt ikke muligt for vores informanter at knytte politikernes anvendelse af nøgletalsrapporten til handlinger og resultater. Vores analyse tyder dermed på, at politikerne generelt ikke skaber handling eller resultater på baggrund af nøgletalsrapporten. Der er kun ét konkret eksempel på, at anvendelsen af nøgletalsrapporten kan kobles direkte til effekter i form af resultater:

„Vi havde ét [eksempel], som vi havde tilbage i 2007 - tror jeg det var - hvor [politikerne] til sidst gav os en besparelse på baggrund af 6-bynøgletallene: 'Hvis I nu skal ned på niveau - det vil betyde, at I vil kunne spare 2 millioner, og vær'sgo: spar det!'“ (Informant M, 6)

Her har nøgletalsrapportens anvendelse fået effekt i form af en faktisk forandring, eftersom nøgletalsrapporten kan knyttes direkte til et fald i udgiftsniveauet. Det er dog det eneste konkrete eksempel, vi har identificeret.

Effekterne af politikernes anvendelse af nøgletalsrapporten materialiserer sig altså som tale og beslutninger og ikke som handlinger og resultater. I tillæg hertil er der kun få konkrete eksempler på effekter i form af tale og beslutninger.

\section{Effekter på det centrale niveau}

Det centrale forvaltningsniveaus anvendelse af nøgletalsrapporten får effekter i form af tale og beslutninger. Der kan ikke i væsentligt omfang identificeres effekter i form af handlinger og resultater. Ligesom for det politiske niveaus anvendelse af nøgletalsrapporten er der få konkrete eksempler på effekter.

Den centrale forvaltning anvender nøgletalsrapporten offensivt over for den decentrale forvaltning. Den centrale del af forvaltningen kan her:

„bruge det offensivt i forhold til en konkret forvaltning og sige: 'I ligger højt'“ (Informant $\cup, 5)$.

Her peger informanten på, at den centrale forvaltnings anvendelse af nøgletalsrapporten har effekt i form af en hensigt om forandring. Effekterne i form af tale kan også være situationer, hvor den centrale del af forvaltningen drøfter mulighederne for forandring og sender et notat med handlingsmuligheder til direktion:

„Når vi sender vores notat [om nøgletalsrapporten] frem til vores direktionen, anbefaler vi nogle ting. 'Skal vi ikke anbefale, at man tager fat i det her?'. Vi udvælger fire-fem steder, hvor vi siger, det kan vi godt grave lidt dybere i og se på, hvorfor vi ligger, som vi gør." (Informant S, 2)

Der er få tilfælde med effekter i form af beslutninger. Vores undersøgelse viser, at økonomiforvaltningerne er interesserede $\mathrm{i}$ argumenter for effektiviseringstiltag (Informant T, 3; Informant N, 2), men også at der ikke er konkrete eksempler på beslutninger taget på baggrund af nøgletallene. Det kan skyldes, at det kan være svært at koble de endelige beslutninger til anvendelsen af nøgletalsrapporten, eftersom mange forhold spiller ind i en ofte kompleks beslutningsproces:

\section{„Om jeg kan komme i tanke om et eksempel på det? Det kan jeg ikke lige. Det ved jeg ikke, om jeg kan, for hvad er nøgletalsrap- port, og hvad er det, at man har kendskab til de andre kommuner? Altså ... Man kan sikkert også sagtens finde eksempler på, at vi skeler til nogle, som ikke lige er del af 6-bykredsen, så jeg ved ikke, om jeg lige kan finde et eksempel på, at man hænger det op på nøgletalsrapporten." (Informant F, 4)}

Der er således en grundlæggende udfordring i entydigt at knytte nøgletallene til forandringer.

Den centrale del af forvaltningen er ansvarlig for administrationsområdet, hvorfor det er den, der skal implementere eventuelle effektiviseringer på området. Her fandt vi kun ét eksempel på, at anvendelsen af nøgletallene har haft effekter i form af faktiske forandringer:

„Og så for nylig her har der jo været administrationsområdet, hvor der er blevet lagt besparelser ind." (Informant P, 3)

Der er altså for det centrale niveaus anvendelse af nøgletalsrapporten nogle, men få eksempler på effekter i form af tale og beslutninger og kun ét eksempel på effekter i form af handling og resultater.

\section{Effekter på det decentrale niveau}

Det decentrale niveaus anvendelse af nøgletalsrapporten har effekter i form af tale og beslutninger. Der kan ikke i væsentligt omfang identificeres effekter i form af handlinger og resultater.

I den decentrale del af forvaltningen er nøgletalsrapporterne et muligt belæg for forandring (Informant $\mathrm{H}$, 1). Effekterne af anvendelsen kommer til udtryk i tale, 
hvor medarbejderne offensivt og defensivt forholder sig til udgiftsniveauerne bl.a. over for medier og politikere:

„Og vi bruger dem jo meget til at synliggøre den effektivitet, hvormed vi driver virksomheden." (Informant I, 1)

Den offensive eller defensive tale kan ses som en hensigt om at skabe forandringer, fordi de rette tal giver mulighed for at få større bevillinger i budgettet eller at blive holdt fri for besparelser:

\section{„Man bruger det både aggressivt for at fremføre ens sag, men man bruger det også defensivt til at forsvare sig. For at sige: 'Jamen det er fordi, vi har valgt at ligge der og der'. Men det, tror jeg, kommer an på den politiske dagsorden på det tidspunkt.“" (Informant M, 9-10)}

Der er også indikationer på indirekte effekter i form af beslutninger, fordi det decentrale forvaltningsniveau anvender nøgletalsrapporterne i forbindelse med de beslutningsprocesser, der foregår i udvalg og byråd:

„Og det er klart, at det er sådan noget, man godt kan bruge til politisk at synliggøre ... i passende sammenhænge ... og også i budgetmæssige sammenhænge - når nu der er nogle behov - så kan man bruge det som en form for dokumentation." (Informant I, 1).

Citatet udtrykker, at det decentrale niveau forsøger at influere beslutningsprocesser ved at tale imod negative forandringer og for fastholdelse af bevillinger. Informanterne fremhæver dog også, at det sker relativt sjældent (Informant T, 4).

Den faktiske forandring, der varetages af den decentrale forvaltning, er implementeringen af de politiske og administrative beslutninger (Informant B, 6). Det er langt fra altid, at disse faktiske forandringer kan knyttes til nøgletal. I flere tilfælde hersker der i den decentrale del af forvaltningen en forestilling om, at forandringerne ikke nødvendigvis bunder i nøgletal, men at nøgletallene anvendes på det politiske niveau til at efterrationalisere forandringerne:

„,[6-bynøgletallene] giver et argument for, at her kan være godt at skære. Når du har besluttet dig for, at det skal være på biblioteksområdet, så kan du sige bagefter: 'Nå ja, men det er også fordi, det bringer os på niveau med [en anden kommune]'. Altså, det er mere et spørgsmål om, at det kan styrke nogle forskellige argumenter og nogle politiske prioriteringer." (Informant L, 3-4)

Samlet set er der kun få eksempler på, at det decentrale niveaus anvendelse af nøgletalsrapporten har effekter $\mathrm{i}$ form af tale og beslutninger. Samtidig får det decentrale niveaus anvendelse af nøgletalsrapporten ikke effekter i form af handling eller resultater - i hvert fald ikke i den intenderede forstand, hvor nøgletalsrapporten anvendes til at skabe faktiske forandringer på et oplyst grundlag.

\section{Delkonklusion}

Kommunernes eget rationale for at deltage i 6-byernes nøgletalssamarbejde bygger på en intention om, at nøgletallene skal give en indsigt og viden, der kan sikre forbedringer gennem faktiske forandringer, dvs. den organisatoriske handlingstype resultater.

Vores analyse har vist, at effekterne af anvendelsen af 6-bynøgletallene overvejende er ens på tværs af de organisatoriske niveauer: Effekterne kommer til udtryk som en hensigt om forandring (dvs. tale og beslutninger) på alle niveauer, mens der kun er enkelte eksempler på faktisk forandring.

Kommunerne opnår dermed kun sjældent de intenderede effekter med anvendelsen. Alligevel består samarbejdet. Vi vender os derfor i diskussionen mod spørgsmålet: Hvad kan forklare, at kommunerne - trods uoverensstemmelsen mellem intentionen og effekterne af anvendelsen - fortsat deltager i samarbejdet?

\section{Hvorfor udarbejdes nøgletalsrapporterne fortsat?}

Dette spørgsmål vil vi diskutere ud fra Mahoneys typologi over forklaringer på institutionel reproduktion.

\section{Forklaringer på bevarelsen af en institution}

Da anvendelsen af 6-bynøgletallene ikke har den intenderede effekt, er det interessant, hvad der i stedet kan forklare, at de seks bykommuner fortsat deltager i det frivillige nøgletalssamarbejde.

Mahoney (2000) beskæftiger sig med, hvorfor institutioner består. Han definerer en institution som "enduring entities that cannot be changed instantaneously or easily" (Mahoney 2000, 512). Ud fra denne definition mener vi, nøgletalsrapporten kan opfattes som en institution, eftersom den er blevet produceret siden $1985 \mathrm{og}$ er svær at ændre, fordi den er indlejret i andre dele af organisationernes arbejde (især budgetbemærkningerne).

Mahoney opstiller en typologi over fire teoretiske forklaringer på institutionel reproduktion: utilitarisme, 
funktionalisme, magt og legitimitet. Vi vil diskutere reproduktionen af nøgletalssamarbejdet ud fra de tre forklaringer, der har aktøren i centrum, hhv. den utilitaristiske, magtorienterede og legitimitetsorienterede forklaring. Den funktionelle forklaring udelades, da vi ikke kan opstille en plausibel systemdrevet forklaring.

Utilitarismeforklaringen indebærer en cost-benefit vurdering af forskellige alternativer, hvor institutionen reproduceres, fordi den er det bedste alternativ (Mahoney 2000, 518). Magtforklaringen fremhæver, at en institution måske ikke er rationel for systemet som helhed, men alligevel reproduceres, fordi eliteaktører efterspørger institutionen og er tilstrækkeligt magtfulde til at sikre reproduktionen (Mahoney 2000, 521). I legitimitetsforklaringen bygger den institutionelle reproduktion på aktørers subjektive forestilling om, hvad der er passende adfærd. Institutioner reproduceres ifølge denne forklaring, fordi aktørerne opfatter dem som værende legitime eller passende (Mahoney 2000, 523).

\section{Den utilitaristiske forklarings styrke}

Vurderingen af den utilitaristiske forklaring ville optimalt bero på en udførlig cost-benefit-analyse af nøgletalsrapporten, men det ligger uden for rammen af denne artikel. I stedet diskuteres fordele og ulemper ud fra de parametre, der kunne indgå i en sådan analyse: validitet, fleksibilitet, udgifter samt netværk og læring. De fire parametre, der er empirisk givne, er opstillet for at kategorisere de argumenter, informanterne brugte til at beskrive og vurdere kilder til nøgletal.

I indledningen nævnte vi, at der findes en række forskellige kilder til nøgletal. Vi diskuterer nedenfor fordele og ulemper ved de kilder, informanterne nævnte i forbindelse med dataindsamlingen. Kilderne er nøgletalsrapporten, KL's Fælleskommunal ledelsesinformation (FLIS), Økonomi- og Indenrigsministeriets kommunale nøgletal ${ }^{2}$ og et sidste alternativ, hvor kommunerne ikke anvender nøgletal.

Som en fordel ved nøgletalsrapporten fremhæver informanterne, at den har en højere kvalitet end de øvrige kilder, da de decentrale forvaltninger selv udarbejder tallene og samarbejder på tværs af kommunerne for at fjerne udfordringer for sammenligneligheden (Informant J, 30; Informant L, 14; Informant S, 11; Informant T, $3)$. Medarbejderne, der til dagligt arbejder med nøgletal, vurderer, at 6-bynøgletallene har en større validitet, fordi de ikke er genereret automatisk, men udarbejdet med udgangspunkt i en faglig indsigt (Informant H, 7-8).

Kildernes fleksibilitet kan afhænge af frekvensen i produktionen af nøgletal og af hvilket niveau, hvorpå tallene er tilgængelige. Nøgletalsrapporten udkommer kun hvert andet år, mens Økonomi- og Indenrigsministeriets kommunale nøgletal og FLIS opdateres månedligt på baggrund af kommunernes indberetninger. Betydningen af frekvensen afhænger af, i hvilken sammenhæng og på hvilket organisatorisk niveau tallene skal bruges. Tallene i nøgletalsrapporterne er på et så aggregeret niveau, at der ikke er store udsving i tallene i perioden mellem udgivelserne (Informant K, 36). Hvis meningen med nøgletallene er at give de decentrale forvaltningsenheder driftsinformation, er en høj frekvens vigtig, hvilket sænker nøgletalsrapportens værdi. Hvis meningen med nøgletalsrapporten derimod er ledelsesinformation, der skal bruges til at skabe overblik med henblik på mulighed for at skabe forandringer, har frekvensen ikke stor betydning for vurderingen af nøgletalsrapporten. Den anden relevante dimension angår niveauet, hvorpå nøgletallene er tilgængelige. FLIS og Økonomi- og Indenrigsministeriets kommunale nøgletal har ikke blot den fordel, at tallene opdateres oftere, men også at tallene findes på flere niveauer. Vurderet ud fra parameteret fleksibilitet er nøgletalsrapporterne det dårligste alternativ efter valget om ingen nøgletal. Den manglende fleksibilitet går især ud over anvendelsesmulighederne på det decentrale niveau i kommunerne. At denne ulempe alligevel ikke forhindrer, at nøgletalsrapporterne reproduceres, kan skyldes, at fleksibilitet ikke er nødvendig for at opfylde intentionen med nøgletallene.

Nøgletalsrapporten er dyrere end Økonomi- og Indenrigsministeriets nøgletal og alternativet med ikke at anvende nøgletal, men nøgletalsrapporten fordrer kun udgifter i medarbejderes timeforbrug. Kommunerne har ikke et konsolideret overblik over udgiften (Informant E, 11), men estimerer, at den er mindre end ved FLIS (Informant D, 12). Da prisen for FLIS er relativ til befolkningstallet, er prisen relativt høj for Danmarks største bykommuner. En af kommunerne eksemplificerer dette med, at udgiften til FLIS ville kunne dække lønningen til to akademiske medarbejdere (Informant J, 12).

Nøgletalsrapporten understøtter en læringsproces og er med til at opbygge et netværk gennem samarbejdet omkring udarbejdelsen af nøgletallene. Det er et netværk, som kommunerne kan trække på, når de ønsker at lære mere om udgiftsdriverne (Informant T, 3). Hverken ved FLIS eller Økonomi- og Indenrigsministeriets kommunale nøgletal er der et samarbejde omkring udarbejdelsen af opgørelserne. Ligesom ved scenariet med ikke at anvende nøgletal styrker anvendelsen af FLIS eller Økonomi- og Indenrigsministeriets kommunale nøgletal derfor ikke netværk og læring. Læringen ville dog alligevel kunne forekomme, da beslutningstagere i kommunerne formentlig alligevel vil efterspørge information om udgiftsdrivere og sammenhængen med budgetternes indretning. 
Ovenstående diskussion kan opsummeres ved at give hver af kilderne til nøgletal en værdi fra ét til fire, hvor ét udtrykker lavest værdi og fire højest værdi.

Som det fremgår af tabel 5.1 nedenfor og diskussionen ovenfor er nøgletalsrapporterne det bedste alternativ, fordi tallene er de mest valide, fordi de indebærer en styrkelse af kommunernes netværk, understøtter læring, og endeligt fordi de er billigere end FLIS. Den utilitaristiske forklaring på institutionel reproduktion har således forklaringskraft. Det skyldes delvist vores ligeværdige vægtning af de fire parametre. Vxgtes parametrene anderledes, kan et andet alternativ være det mest fordelagtige. Kommunerne har ikke vurderet den relative vægt af de forskellige parametre, men validitet fremhæves som en central værdi, hvilket understøtter nøgletalsrapporterne som det bedste alternativ og dermed den utilitaristiske forklaring:

„Så hele nøgletalsdiskussionen er ikke i dag om at skabe nøgletal. I dag er det om at sende de rigtige nøgletal af sted: Hvad er de rigtige, hvad har man brug for, hvad er validt, osv. I den sammenhæeng er 6-bynøgletallene, fordi de er så gennemarbejdede, som de er, og fordi de bliver revideret hver gang, ret fornuftige. Det er mit indtryk i hvert fald." (Informant L, 10)

Ovenstående understøtter, at den utilitaristiske forklaring finder opbakning. Når nøgletal efterspørges, er det, fordi nøgletalsrapporten er det alternativ, der bedst opfylder et opfattet behov.
Den magtorienterede forklarings styrke

Magtforklaringen har forklaringskraft i vores case, hvis vi kan vise, at der hersker et generelt ønske om at ændre eller afskaffe nøgletalssamarbejdet, men at en magtfuld elites $ø$ nske om at bevare det betyder, at kommunerne fortsætter med at udarbejde nøgletalsrapporten. Det indebærer, at fordele og ulemper ved nøgletalssamarbejdet er skævt fordelt i mellem grupperinger med forskellig magt, og at en magtfuld elite har nettogevinster.

Kommunerne fremhæver, at nøgletallene efterspørges af politikere og topembedsmænd:

„Jeg vil sige, det primært er politisk drevet ønske, at vi fortsat laver det“ (Informant F, 3)

„Det er vores politikere og topembedsmænd, som gerne vil have, at vi laver den [nøgletalsrapporten]." (Informant P, 2)

„Der er ikke sådan nogen, der siger: 'Vi vil have dem'. Altså jo, økonomidirektørerne kan godt snakke en lille smule om det, men det er jo ikke fordi, at det ville stoppe jorden fra at dreje, hvis [nøgletalsrapporterne] ikke kom“ (Informant E, 10)
„Altså, rapporten bliver besluttet i kredsen af økonomichefer i 6-bysamarbejdet, og de er jo grundlæggende glade for sådan en rapport, og de bakker op om den." (Informant $\cup, 2)$

Citaterne peger på, at det er politikere og topembedsmænd, der efterspørger nøgletallene. Politikerne og topembedsmændene kan opfattes som en elite, da de med

Tabel 5.1: Display over kilderne til nøgletals værdi ud fra parametrene validitet, fleksibilitet, udgift samt netværk og læring

\begin{tabular}{|l|c|c|c|c|c|}
\hline & Validitet & Fleksibilitet & Udgift & Netværk og læring & Værdi \\
\hline Nøgletalsrapporten & 4 & 2 & 2 & 4 & 12 \\
\hline IM & 2 & 3 & 4 & 1 & 10 \\
\hline FLIS & 3 & 4 & 1 & 1 & 9 \\
\hline Ingen nøgletal & 1 & 1 & 4 & 1 & 7 \\
\hline
\end{tabular}

Kilde: Input fra informanterne og egen diskussion (Brødsgaard \& Gjørling 2015, 140).

Note: Et højt tal indikerer en høj værdi. Flere kilder til nøgletal kan have samme værdi som fx ved netværk og læring, hvis det er vurderet, at deres værdi på dette parameter er ensartet. 
hhv. beslutningskompetence og hierarkiske relationer til resten af embedsapparatet indtager privilegerede roller. Politikernes og økonomichefernes rolle er ikke entydig, men man kan argumentere for, at begge grupper kan ses som aktører, der efterspørger nøgletallene, og dermed er med til at promovere reproduktionen.

Nogle informanter fremhæver, hvordan de har forsøgt at få ændret nøgletalsrapporten:

\section{„Altså vi har jo også flere gange stillet forslag om, at [nøgletalsrapporten] skulle laves lidt mere i en pixi-agtig udgave eller ikke være så omfattende, som den er lige nu, men det er økonomicheferne og politikerne ikke parate til“. (Informant P, 3)}

Når der flere gange er blevet stillet ændringsforslag, tyder det på, at der hersker et ønske om at ændre institutionen. Forslagene om ændringer omhandlede ønsket om at gøre nøgletalsrapporten mindre omfangsrig, men som det fremgår af citatet ovenfor, blev forslagene ikke vedtaget, netop fordi økonomicheferne i styregruppen og politikerne ikke var parate til det.

Det tyder på, at topembedsmænd og politikerne har en særlig styrke i relationen til de andre grupperinger, der gør det muligt for dem at promovere reproduktionen af nøgletalssamarbejdet, selvom der bliver stillet forslag om en forandring. Det er ikke blot den centrale del af forvaltningens embedsmænd, der er modstandere af reproduktionen. Det primære budskab fra den decentrale forvaltning var, at man ikke så stor værdi i nøgletallene:

„[Værdien] ser vi ikke ret meget af. Umiddelbart tænker jeg, at det ikke er noget, vi skal bruge ret meget tid på. For det er ikke noget, vi bruger." (Informant G, 1)

Det er således sammenfaldende med magtforklaringen, at der er en skæv fordeling af fordele og ulemper, og at reproduktionen forekommer, fordi en elite har nettofordele og styrken til at kræve reproduktionen.

\section{Den legitimitetsorienterede forklarings styrke}

Ifølge Mahoney (2000) kan reproduktion også skyldes institutionens legitimitet.

Det centrale i legitimitetsforklaringen er aktørers subjektive forestillinger om det passende. Dermed bliver det relevant at forholde sig til, hvad der påvirker disse subjektive forestillinger. Mahoney (2000) refererer i sin artikel til Meyer og Rowans (1977) forståelse af, at legitimitet hænger sammen med rationaliserede myter, institutioners effektivitet og stabilitet samt politiske lederes idéer. Ra- tionaliserede myter kan være sammenhængende med det herskende styringsparadigme ${ }^{3}$ :

„Det er det økonomiske rationale, der har
grebet os alle sammen“ (Informant I, 2)

Det fremhæves i citatet, at det økonomiske rationale fylder meget i bevidstheden hos kommunen, og herunder at udarbejdelsen af nøgletalsrapporterne kan ses som en del af kommunernes forsøg på at blive opfattet som legitime.

Ifølge den legitimitetsorienterede forklaring er kommunerne for at fremstå legitime presset til at ,incorporate the practices and procedures defined by prevailing rationalized concepts of organizational work and institutionalized in society" (Meyer \& Rowan 1977, 340).

Man kan altså argumentere for, at nøgletalsrapporterne kan ses som en praksis defineret af det herskende paradigme: det økonomiske rationale. Det underbygges af intentionen med nøgletalssamarbejdet: Der hersker en forestilling om, at nøgletalssamarbejdet er nødvendigt (Informant P, 4).

Meget tyder på, at udarbejdelsen af nøgletalsrapporterne opfattes som passende adfærd, hvorfor den legitimitetsorienterede forklaring har en vis styrke.

\section{Delkonklusion}

Diskussionen pegede på, at den utilitaristiske, den magtorienterede og den legitimitetsorienterede forklaring har forklaringskraft.

Nøgletalsrapporten er det bedste alternativ, det er medvirkende til at legitimere kommunerne, og samtidigt er der en skæv fordeling af fordele og ulemper. Det er ikke muligt entydigt at afgøre, hvilken af de tre forklaringer, der har størst forklaringskraft, men det er på baggrund af den skæve fordeling af fordele og ulemper samt informanternes udsagn vores umiddelbare vurdering, at magtforklaringen kan hævdes at have størst forklaringskraft. Nøgletalsrapporten bestilles af politikere og topembedsmænd, og især på det decentrale forvaltningsniveau er der et ønske om at ændre eller afskaffe rapporterne. Det er ikke klart, om rapporterne bestilles, fordi der er et ønske om denne type information, og nøgletalsrapporten er det bedste alternativ, eller fordi udarbejdelsen af rapporterne opfattes som „passende“.

Alle tre forklaringer har forklaringskraft og kan i varierende grad bidrage til at forstå, hvorfor nøgletalsrapporterne stadig udarbejdes, selvom de ikke har de intenderede effekter.

\section{Konklusion}

På baggrund af en undren over effekterne af anvendelsen af benchmarking i den kommunale sektor, spurgte vi 
indledningsvist, hvorfor Danmarks seks største bykommuner deltager $\mathrm{i}$ et frivilligt nøgletalssamarbejde.

Vores analyse viste, at der ikke er sammenhæng mellem intentionen med nøgletalssamarbejdet og effekterne af anvendelsen af det. Det var kommunernes intention, at anvendelsen af nøgletallene skulle lede til forbedringer gennem faktiske forandringer, men effekterne kom overvejende til udtryk som en hensigt om forandring og kun i enkelte tilfælde som faktisk forandring.

Det ledte os til i diskussionen at spørge, hvilke alternative forklaringer der kunne være på, hvorfor kommunerne fortsat udarbejder nøgletalsrapporterne. Vi fremhævede i diskussionen, at den magtorienterede forklaring har størst forklaringskraft, men at vi ikke kan afgøre, om den elite inden for kommunen, der efterspørger nøgletallene, gør det ud fra et utilitaristisk eller et legitimerende hensyn, hvorfor alle tre forklaringer har fundet opbakning.

Vi kan konkludere, at Danmarks seks største bykommuner deltager i et frivilligt nøgletalssamarbejde, fordi politikere og topembedsmænd ønsker det. Det kan både skyldes, at samarbejdet anses for at være den bedste balancering af valid information, fleksibilitet, udgift og styrkelse af netværk og læring, og at anvendelsen af nøgletal understøtter kommunens forsøg på at blive opfattet som legitim. Det er uklart, om nøgletalssamarbejdet reproduceres ud fra en konsekvens- eller legitimitetslogik (March \& Olsen, 1989). Det kan være knyttet til, at nogle værdier internaliseres (Vygotsky 1978, 57) i en sådan grad, at det kan være svært at skelne mellem rationelle og legitimerende hensyn. Med udgangspunkt i Brunsson kan vi argumentere for, at netop fordi kommunerne både har et teknisk og institutionelt miljø, må kommunerne i opgaveløsningen henvende sig til begge. Nøgletalsrapporterne kunne dermed være et eksempel på, at det tekniske og institutionelle miljø tilgodeses samtidigt. Dog er det tvivlsomt, om det tekniske miljø reelt tilgodeses, når anvendelsen af nøgletallene i så få tilfælde leder til faktiske forandringer.

Da det ikke er muligt for os at konkludere, om utilitariske hensyn eller legitimitet vejer tungest, er der behov for, at der med udgangspunkt i denne artikels konklusioner foretages en mere systematisk undersøgelse af elitens bevæggrund for reproduktionen af nøgletalsrapporterne.

Ligeledes kan det være værdifuldt for kommunerne med udgangspunkt i disse konklusioner at revurdere, om de mener, at de høster tilstrækkelige fordele relativt til de ulemper, produktionen af nøgletal trods alt indebærer.

Denne artikel peger i relation til tidsskriftets tema på, at elementer af resultatstyring ikke altid anvendes på den intenderede måde, ikke har de ønskede effekter, og at det dertil er uklart, præcist hvorfor man fortsat anvender det.

\section{Litteratur}

Askim, J., Båtsvik, T. \& Skattum, C., 2007. Fører benchmarking til forbedringer i kommunene? Erfaringer fra Effektiviseringsnettverkene, 2002-2005.

Baes-Jørgensen, J., 2013. Et valg i krisebevidsthedens tegn. kl.dk. Available at: http://www.kl.dk/Momentum/momentum201313-1-id137004/?n=0 [Accessed June 22, 2014].

Behn, R., 2003. Why Measure Performance? Different Purposes Require Different Measures. Public Administration Review, 63(5), pp.586-605.

Bøgh Andersen, L., Skorkjær Binderkrantz, A. \& Møller Hansen, K., 2010. Forskningsdesign. In L. Bøgh Andersen, K. Møller Hansen, \& R. Klemmensen, eds. Metoder i statskundskab. pp. 66-96.

Brødsgaard, M.-L.F. \& Gjørling, M., 2015. Effekter af anvendelsen af benchmarking $i$ den kommunale sektor - en undersogelse af hvorfor Danmarks seks storste bykommuner deltager $i$ et frivilligt nogletalssamarbejde. København: Københavns Universitet.

Brunsson, N., 2002. The organization of hypocrisy : talk, decisions, and actions in organizations 2nd ed., København: Copenhagen Business School Press.

Bukh, P.N., 2007a. Benchmarking: Et paraplybegreb. Fjernvarmen, 2007(9), pp. 22-24.

Bukh, P.N., 2007b. Benchmarking: Principper, metoder og udfordringer. In Ledelsehåndbogen Strategi og Ledelse. Børsen Forum A/S, Børsen Ledelseshåndbøger, pp. 1-26. Available at: http://www.pnbukh. com/files/nyheder/SOL.01.09_Benchmarking.pdf.

Campbell, J.L., 1998. Institutional analysis and the role of ideas in political economy. Theory and Society, 27(3), pp. 377-409.

Van Helden, G.J. \& Tillema, S., 2005. In Search of a Benchmarking Theory for the Public Sector. Financial Accountability \& Management, 21(3), pp.337-361.

Københavns Kommune, 2013. 6-bynøgletal. Available at: http:// www.kk.dk/da/om-kommunen/indsatsomraader-og-politikker/ oekonomi-og-organisation/6-by-noegletal [Accessed December 17, 2014].

Konkurrencestyrelsen, 1998. Redegørelse om benchmarking, Konkurrencestyrelsen.

Mahoney, J., 2000. Path dependence in historical sociology. Theory and Society, 29(4), pp. 507-548.

Mahoney, J., 2000. Path Dependence in Historical Sociology. Theory and Society, 29(4), pp. 507-548.

Meyer, J.W. \& Rowan, B., 1977. Institutionalized organizations: Formal structure as myth and ceremony. American journal of sociology, 83(2), p. 340.

Olsen, A.L., forthcoming. Naming Bad Performance: Can Performance Disclosure Drive Improvements?

Polkinghorne, D.E., 2005. Language and meaning: Data collection in qualitative research. Journal of Counseling Psychology, 52(2), pp. $137-145$.

Pollitt, C., 2001. Convergence: The Useful Myth? Public Administration, 79(4), pp. 933-947.

Siverbo, S. \& Johansson, T., 2006. Relative Performance Evaluation in Swedish Local Government. Financial Accountability and Management, 22(3), pp. 271-290.

Stubager, R. et al., 2013. Danske vælgere 1971-2011 - en oversigt over udviklingen i vælgernes holdninger mv.

Triantafillou, P., 2007. Benchmarking in the Public Sector: A Critical Conceptual Framework. Public Administration, 85(3), pp. 829-846. 


\section{Noter}

1. Beskrivelsen af kommunernes intention med nøgletalssamarbejdet bygger udelukkende på informanternes oplevelse af intentionen, da det i forbindelse med vores undersøgelse stod klart, at der ikke foreligger skriftlig dokumentation for arbejdet i nøgletalssamarbejdet.

2. Flere informanter benævner Økonomi- og Indenrigsministeriets kommunale nøgletal som Indenrigsministeriets nøgletal eller blot IM's nøgletal.
Økonomi- og Indenrigsministeriets nøgletal bygger på den autoriserede kontoplan for kommunernes budget- og regnskabssystem. Indenrigsministeriet har defineret 191 nøgletal, der i forskellige sorteringer og udviklingstyper kan opgøres på tværs af kommuner og over tid. Opgørelserne bygger på tal, der indberettes af kommunerne (Brødsgaard \& Gjørling 2015, 134).

3. Campbell definerer et paradigme som et sæt af basale teoretiske og ontologiske antagelser, som er definerende for det politiske landskab (Campbell 1998, 389).

\section{Bilag 1. Oversigt over informanterne}

\begin{tabular}{|c|c|c|}
\hline Informant & Stilling & Kommune \\
\hline Informant A & Økonomidirektør, Central forvaltning & Kommune 1 \\
\hline Informant B & Sekretariatschef, Decentral forvaltning & Kommune 1 \\
\hline Informant C & Fuldmægtig, Central forvaltning & Kommune 1 \\
\hline Informant D & Økonomisk konsulent, Central forvaltning & Kommune 2 \\
\hline Informant E & Konsulent, Central forvaltning & Kommune 2 \\
\hline Informant F & Kontorchef, Central forvaltning & Kommune 2 \\
\hline Informant G & Specialkonsulent, Decentral forvaltning & Kommune 2 \\
\hline Informant H & Sektionschef, Decentral forvaltning & Kommune 2 \\
\hline Informant I & Forvaltningschef, Decentral forvaltning & Kommune 2 \\
\hline Informant J & Konsulent, Central forvaltning & Kommune 3 \\
\hline Informant K & Kontorchef, Central forvaltning & Kommune 3 \\
\hline Informant L & Økonomikonsulent, Decentral forvaltning & Kommune 3 \\
\hline Informant M & Leder, Decentral forvaltning & Kommune 3 \\
\hline Informant N & Kontorchef, Central forvaltning & Kommune 4 \\
\hline Informant 0 & Økonomisk Konsulent, Central forvaltning & Kommune 4 \\
\hline Informant $P$ & Specialkonsulent, Central forvaltning & Kommune 4 \\
\hline Informant Q & Fuldmægtig, Decentral forvaltning & Kommune 4 \\
\hline Informant $\mathrm{R}$ & Teamleder, Decentral forvaltning & Kommune 4 \\
\hline Informant S & Projektleder, Central forvaltning & Kommune 5 \\
\hline Informant T & Chefkonsulent, Decentral forvaltning & Kommune 6 \\
\hline Informant U & Kontorchef, Central forvaltning & Kommune 6 \\
\hline Informant V & Fuldmægtig, Central forvaltning & Kommune 6 \\
\hline
\end{tabular}

